\title{
Jakub J. Czarkowski, Mariusz Malinowski, Marcin Strzelec, Maciej Tanaś (Eds.) (2020). Zdalne kształcenie akademickie dorostych w czasie pandemii. [Distance Academic Adult Education During the Pandemic]. Warszawa: Wy- dawnictwo DiG, pp. 311. ISBN 978-83-286-0120-8
}

The epidemiological threat connected to the spread of COVID-19, disrupting our work and social life in spring 2020, has disrupted the system of education and university instruction as well. It forced lecturers to take immediate action to ensure the continuity of teaching. Students could not be left without academic support and supervision. However, we were not properly prepared for the situation, which was rapidly changing. The experiences of the lecturers from various Polish universities who faced unprecedented challenges when conducting research and providing instruction to university students during the pandemic, were gathered in the volume published by the DiG Publishing House entitled Zdalne ksztatcenie akademickie dorostych $w$ czasie pandemii [Distance Academic Adult Education During the Pandemic].

The main problems in continuing university instruction in the new form, indicated by the editors of the volume, are primarily: the information technology gap (lack of appropriate equipment or technical support); situational information gap (lack of preparation and competences necessary to ensure effective organization of education in crisis); fear of the new problems, which the situation presents us with; lack of appropriate organizational and legal solutions; and, finally, lack of knowledge on how to support students in crisis. In recent months, we have all faced such challenges. The authors of the texts published in the reviewed volume analyze this situation.

This publication is a result of a joint project, carried out under the direction of the scientific editors of this volume. It was completed thanks to the cooperation of virtual teams, communicating with each other and exchanging their experiences. Close collaboration of the authors and the editors made the book more cohesive and ensured that its analysis of the impact of the pandemic on higher education would be comprehensive.

The book is divided into four parts. First part (Uwarunkowania edukacji zdalnej [Conditions of distance education]) discusses the reality of learning and teaching under the conditions of social distancing (distance learning), taking into account the multifaceted nature of this phenomenon. The articles in this part primarily focus on the sociology and psychology of the Internet.

The opening text of the volume, describing university instruction in the first days after the suspension of regular stationary teaching classes, resembles a battlefield report. Many of us shared the author's feelings. The first weeks of the pandemic were a period of transition from disorientation to mobilization.

The second article does not discuss distance learning in the time of pandemic directly; rather, it concerns the changes in the information society resulting from the technological development which accompanied the introduction of distance learning as the new norm. The following article, devoted to adult learning, including distance learning, is equally general. The authors stress the importance of the fit between a student's personality and the teaching methods. To teach effectively, the lecturer should choose right incentives, taking into account each student's characteristics. The conditions of distance learning make it virtually impossible for the lecturer to get a sense of their students' personalities required for a close match of learning methods - it seems like an important issue, but the authors do not mention it. However, they discuss another challenge of distance learning, i.e., the integration of the virtual group. It would require so much preparation, work and time that in practice, that in current circumstances it cannot be accomplished. 
Another author, focusing on the sociology of online education, directs our attention to the fact that distance learning, which until recently was a complementary method, has out of necessity suddenly become the dominant method. The consequences of the (so far, temporary) virtualization of many social phenomena (including work and education) may be irreversible. The last text of this section studies distance learning in the context of the evolution of media (traditional and digital).

The second part (Okruchy dydaktyki [The crumbs of didactics]) is more theoretical. The first text in this section presents theoretical models of distance learning for adults. The aim of this theoretical review is to give the teachers a choice of methods suited to the needs of particular classes and groups of students to achieve the best possible learning outcomes. An important aspect of the crisis situation are the greater expectations from students to self-educate. In order for self-education to be effective, it is necessary to activate mindsets other than those important in the process of traditional education, such as motivation, discipline, ability to organize one's work, commitment, activity, etc. This is an important issue for lecturers, who should know how to encourage their students to study by themselves. Finally, the last article in this section is a synthetic summary of e-learning as a form and way of adult education.

The third part (Narzędzia $i$ metody [Tools and methods]) is devoted to the practical aspects of distance education, i.e., the methods and tools of education. The first text in this section presents various didactic methods that can be used in distance learning. The following article discusses specific IT tools to be used in this process. The third text includes practical advice on preparing webinars and video lectures. The fourth and fifth articles are devoted to the use of social networks in education. The sixth text presents programs suited to preparing educational materials (e.g. creating graphic, audio and video files). The title of the seventh article (Tablet $i$ telefon $w$ ksztatceniu zdalnym [Tablet and phone in distance learning]) suggests that it will discuss the use of mobile devices in distance learning. However, this is not the case. In fact, the author, who is very critical of academic lecturers, focuses on the psychology of contacts between lecturers and students, and their mutual (usually negative) perception and generational differences. Finally, the last text of this section is devoted to quality control of distance education.

The fourth part (Kilka kwestii na zakończenie tomu [Several issues to conclude the volume]) is a collection of various texts, which are not directly related to the main theme, but, according to the publishers, speak to the issues related to distance learning using modern digital technologies. The section comprises an article titled Niektóre prawne uwarunkowania organizacji i prowadzenia zajęć zdalnych z zastosowaniem technologii informatycznych [Certain legal conditions for the organization and conducting of distance learning with the use of information technologies], and texts on academic education of seniors, and on the issue of complementary education, which close the volume.

It is still too early to formulate a satisfying summary of the phenomena associated with the pandemic. We remain stuck struggling with the challenges of this new normal. All we can do right now is describe the processes that are currently taking place, the ways in which we adapt and manage the crisis, and, finally, the methods and tools we currently use. More in-depth analyses can only be made retrospectively. However, it already seems obvious that one of the most lasting effects of the pandemic will be the development of distance learning and the associated technologies. Nevertheless, we have to be aware that, as research indicates, "the social experience gained through the distance education process seems many times poorer than that available through direct education" (p. 289). E-learning therefore will not be able to completely replace personal contacts and traditional meetings in the lecture theatre.

The texts collected in reviewed volume have been thoughtfully selected and arranged; they constitute a coherent and logical whole, complementing and explaining each other. They are written by scholars representing different scientific disciplines. They discuss practical experiences, outline methodological frameworks, and present theoretical and historical reflections (the development of certain phenomena related to education, including e-learning, and media). 
This book is an important and interesting publication, serving primarily as a witness to the first period of the pandemic, when we were confronted with a new reality and forced to adapt quickly to it. The lecturers, who have not yet managed to adjust to the new situation for various reasons, may find here potential solutions, techniques, methods and tools to use in the future. Surely everyone will find something for themselves. Finally, this volume systematizes our initial experience of lockdown. It should attract the attention of the university lecturers, educators and people interested in the issues of education, especially distance education.

Piotr Tafiłowski

ORCID 0000-0003-2798-3249

Department of Information Studies

Faculty of Journalism, Information and Book Studies University of Warsaw, Poland

Received: 8 September 2020. 